\title{
Complete genome sequence of Streptococcus agalactiae strain SA20-06, a fish pathogen associated to meningoencephalitis outbreaks
}

\author{
Ulisses de Pádua Pereira ${ }^{1,4}$, Anderson Rodrigues dos Santos², Syed Shah Hassan², Flávia \\ Figueira Aburjaile ${ }^{2}$, Siomar de Castro Soares ${ }^{2}$, Rommel Thiago Jucá Ramos $^{3}$, Adriana Ribeiro \\ Carneiro $^{3}$, Luís Carlos Guimarães ${ }^{2}$, Sintia Silva de Almeida ${ }^{2}$, Carlos Augusto Almeida Diniz², \\ Maria Silvanira Barbosa ${ }^{3}$, Pablo Gomes de Sá ${ }^{3}$, Amjad Ali², Syeda Marriam Bakhtiar², \\ Fernanda Alves Dorella2 ${ }^{2}$, Adhemar Zerlotini ${ }^{5,6}$, Flávio Marcos Gomes Araújo ${ }^{5}$, Laura Rabelo \\ Leite $^{5}$, Guilherme Oliveira ${ }^{5}$, Anderson Miyoshi' ${ }^{2}$, Artur Silva ${ }^{3}$, Vasco Azevedo², Henrique \\ César Pereira Figueiredo ${ }^{1^{*}}$ \\ ${ }^{1}$ AQUAVET- Laboratory of Aquatic Animal Diseases, Department of Preventive Veterinary \\ Medicine, Federal University of Minas Gerais, Belo Horizonte, MG, Brazil \\ 2 Institute of Biologic Sciences, Federal University of Minas Gerais, Belo Horizonte, MG, \\ Brazil \\ ${ }^{3}$ Institute of Biologic Sciences, Federal University of Pará, Belém, PA, Brazil \\ ${ }^{4}$ Department of Veterinary Medicine, Federal University of Lavras, Lavras, MG, Brazil \\ ${ }^{5}$ Center for Excellence in Bioinformatics - FIOCRUZ-MG, Belo Horizonte, MG, Brazil \\ ${ }^{6}$ Bioinformatics Multiuser Laboratory - Embrapa, Campinas, SP, Brazil
}

*Correspondence: Henrique C. P. Figueiredo, DVM, Ph.D. (henrique@dmv.ufla.br)

Keywords: Streptococcus agalactiae, fish pathogen, genome sequencing

Streptococcus agalactiae (Lancefield group B; GBS) is the causative agent of
meningoencephalitis in fish, mastitis in cows, and neonatal sepsis in humans.
Meningoencephalitis is a major health problem for tilapia farming and is responsible for high
economic losses worldwide. Despite its importance, the genomic characteristics and the
main molecular mechanisms involved in virulence of S. agalactiae isolated from fish are still
poorly understood. Here, we present the genomic features of the 1,820,886 bp long complete
genome sequence of S. agalactiae SA20-06 isolated from a meningoencephalitis outbreak in
Nile tilapia (Oreochromis niloticus) from Brazil, and its annotation, consisting of 1,710 pro-
tein-coding genes (excluding pseudogenes), 7 rRNA operons, 79 tRNA genes and 62
pseudogenes.

\section{Introduction}

Streptococcus agalactiae, also referred as Group B Streptococcus (GBS), is a Gram-positive pathogen with a broad host range. GBS is the most common cause of life-threatening bacterial infections in human newborns [1] and is an important etiological agent of clinical and sub-clinical bovine mastitis [2]. In fish, S. agalactiae infection causes septicemia and meningoencephalitis, mainly in warm water species from freshwater, marine, or estuarine environments [3]. Currently, S. agalactiae is an emerging pathogen associated with severe economic losses due to high mortality rates in fish farms worldwide $[4,5]$.
The pangenome of the species (obtained from only eight human strain genomes) is considered open and it is expected that, for every new GBS genome sequenced, approximately 33 new strain-specific genes will be identified [6]. Since, the first genome of $S$. agalactiae strain isolated from bovine mastitis was published and 183 strain-specific genes were described, and about $85 \%$ of these genes have been clustered into eight genome islands, strongly suggesting that these genes were acquired through lateral gene transfer from other bacteria of genus Streptococcus, which are also etiologic agents of bovine mastitis [2]. However, 
the molecular mechanisms of virulence and other genomic features of strains isolated from fish isolates remain unclear, and thus, the genome sequencing of different strains isolated from other hosts are still required to better understand the global complexity of this bacterial species.

\section{Classification and Features}

The genus Streptococcus comprises a heterogeneous group of bacteria that have an important role in medicine and industry. These microorganisms are Gram-positive, cocci, 0.6-1.2 $\mu \mathrm{m}$ diameter, not motile, do not form spores, are catalasenegative and grow in pairs or chains [7]. Rebecca C. Lancefield, in her work in the early 1930s, systematized the classification of streptococci based on the presence and type of surface antigen: cell wall polysaccharide or lipoteichoic acid [8]. $S$. agalactiae is classified as Lancefield group B (GBS) based on the presence of a polysaccharide in the cell wall. This polysaccharide is composed of galactose, $\mathrm{N}$-acetylglucosamine, rhamnose and glucitol phosphate [7].Currently, ten serotypes are described for this species (Ia, Ib, II-IX) and occasionally some strains can be nonserotypeable [9].

Major human and animal streptococcal pathogens belong to the pyogenic group of $\beta$-hemolytic streptococci [10]. In this context, the $\beta$ - hemolytic bacteria $S$. agalactiae, deserves attention for causing diseases in a broad range of homeothermic and heterothermic hosts [4], although this bacteria is also a common member of the gastrointestinal tract microbiota [11].

At the end of the 19th century, GBS was initially described as an etiological agent of mastitis in cows, being reported as causing disease in humans only 50 years later [12]. In fish, $S$. agalactiae was recognized as a pathogen in 1966 [13]. Sporadically, this pathogen has also been associated with illness in many others hosts, such as chickens, camels, dogs, horses, cats, frogs, hamsters, mice, monkeys, and nutria [14].

S. agalactiae is a facultatively anaerobic bacterium that uses glucose as an energy source, and is also able to use different carbon sources such as cellobioise, beta-glucoside, trehalose, mannose, lactose, fructose, mannitol, Nacetylgalactosamine, and glucose (Table 1). This pathogen is limited in the synthesis of most amino acids precursors. Only the biosynthetic pathways for alanine, serine, glycine, glutamine, aspartate, asparagine and threonine are present [31]. The adaptation to oxygen radical stress of this pathogen is related to superoxide dismutase ( $\operatorname{sod} A$ gene) which converts superoxide anions to molecular oxygen and hydrogen peroxide, which, in turn, is metabolized by catalases and/or peroxidases [34]. Although GBS does not synthetize catalase to remove toxic $\mathrm{H}_{2} \mathrm{O}_{2}$, it is 10 -fold more resistant to oxygen metabolites than the catalaseproducing $S$. aureus. This is due to the presence of several enzymes that might detoxify $\mathrm{H}_{2} \mathrm{O}_{2}$ that have been identified in the genome of $S$. agalactiae such as NADH peroxidase, NADH oxidase and thiol peroxidase [31]. This diversity of metabolic and adaptative mechanisms reflects the ability of GSB to survive in various environments and hosts.

The phylogenetic tree was constructed using $16 \mathrm{~S}$ rRNA sequences of available $S$. agalactiae genomes and other species from the same genus (Figure1). The tree shows that all $S$. agalactiae strains are grouped together, and the SA20-06 strain is more similar to the A909 human isolate and to the GD201008-001 fish isolate from China.

\section{Genome sequencing and annotation Genome project history}

This strain was selected for sequencing based on the high mortality rates shown for this pathogen in fish farms worldwide and on the lack of information for the genomic characteristics of $S$. agalactiae isolated from fish and the molecular mechanisms involved in virulence in this host. The genome project is deposited in the Genomes On Line Database [37] and the Streptococcus agalactiae SA20-06 complete genome sequence and annotation data were deposited in the DDBJ/EMBL/GenBank under the accession number CP003919 (RefSeq NC_019048). Sequencing, assembly steps, finishing and annotation were performed by the teams from the Laboratory of Cellular and Molecular Genetics (LGCM), Minas Gerais, Brazil; Genomics and Proteomics Network of the State of Pará (RPGP), Pará, Brazil and Center for Excellence in Bioinformatics (CEBioFIOCRUZ-MG), Minas Gerais, Brazil. A summary of the project information is shown in Table 2. 


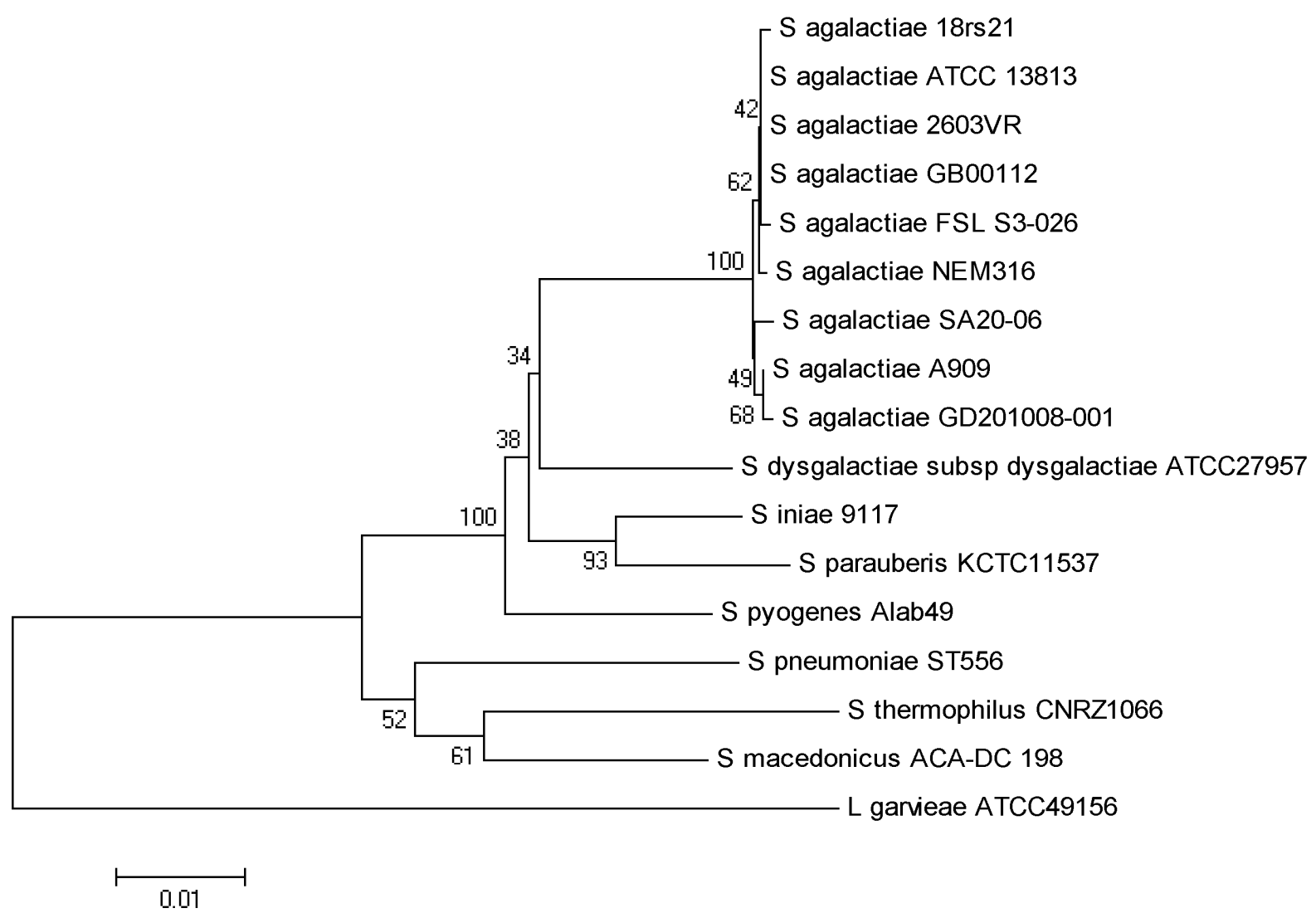

Figure 1. Phylogenetic tree highlighting the position of $S$. agalactiae strain SA20-06 in relation to other selected strains of the species and others from the genus Streptococcus. The tree was based on 1,410 characters of the 16S rRNA gene sequence aligned using ClustalW2 [35]. The tree was inferred under the maximum likelihood criterion using MEGA5 software [36] and rooted with $16 \mathrm{~S}$ rRNA sequence of fish pathogen Lactococcus garvieae (a member of the Streptococcaceae). The branches were mapped by the expected number of substitutions per site. The numbers above the branches are support values from 1,000 bootstrap replicates. The strains and their corresponding GenBank accession numbers (and, when applicable, draft sequence coordinates) for 16S rRNA genes are: S. agalactiae 18rs21, NZ_AAJO01000124; S. agalactiae ATCC13813, NR_040821; S. agalactiae 2603VR, NC_004116; S. agalactiae GB00112, AKXO01000029; S. agalactiae FSL_S3-026, AEXT01000002; S. agalactiae NEM316, AL766845; S. agalactiae SA20-06, NC_019048; S. agalactiae A909, NC_007432; S. agalactiae GD201008-001, CP003810; S. dysgalactiae subsp dysgalactiae ATCC 27957, CM001076; S. iniae 9117, NZ_AMOO01000003; S. parauberis KCT 11537, NC_015558; S. pyogenes alab49, NC_017596; S. pneumoniae ST556, NC_017769; S. thermophilus CNRZ1066, NC_006449; S. macedonicus ACA-DC 198, NC_016749; L. garvieae, AP009332.

\section{Growth conditions and DNA isolation}

Streptococcus agalactiae SA20-06 was obtained from the AQUAVET (Laboratory of Aquatic Animal Diseases) bacterial collection, streaked onto $5 \%$ sheep blood agar and incubated at $28^{\circ} \mathrm{C}$ for $48 \mathrm{~h}$. After that, cells were grown in $150 \mathrm{~mL}$ brain-heartinfusion broth (BHI-HiMedia Laboratories Pvt. Ltda, India) under agitation $(150 \mathrm{rpm})$, at $28^{\circ} \mathrm{C}$. Genomic DNA was obtained by using phenolchloroform-isoamylic alcohol extraction protocol using micro-wave oven [38].

\section{Genome sequencing and assembly}

The genome sequencing of $S$. agalactiae SA20-06 was performed using the SOLiD v3 Plus and SOLiD 5500 platforms (Applied Biosystems) with two mate-paired libraries (both with 1-2 kb insert size), which generated 50,223,637 and $283,953,694$ reads of $50 \mathrm{bp}$ and $60 \mathrm{bp}$ in size, respectively. After sequencing, the reads were subjected to quality filtering using the qualityFilter.pl script (a homemade script), in which reads with an average Phred quality of less than 20 were removed, and error sequence correction was performed with SAET software (Life Technologies). 
de Pádua Pereira et al.

Table 1. Classification and general features of S. agalactiae SA20-06 according to the MIGS recommendations [15].

\begin{tabular}{|c|c|c|c|}
\hline MIGS ID & Property & Term & Evidence code \\
\hline & \multirow{8}{*}{ Classification } & Domain Bacteria & TAS [16] \\
\hline & & Phylum Firmicutes & TAS [17-19] \\
\hline & & Class Bacilli & TAS $[20,21]$ \\
\hline & & Order Lactobacillales & TAS $[20,22]$ \\
\hline & & Family Streptococcaceae & TAS $[23,24]$ \\
\hline & & Genus Streptococcus & TAS $[23,25,26]$ \\
\hline & & Species Streptococcus agalactiae & TAS [23,27-29] \\
\hline & & Strain SA20-06 & TAS [4] \\
\hline & Gram stain & Positive & TAS [30] \\
\hline & Cell shape & Spherical or ovoid & TAS [30] \\
\hline & Motility & non-motile & TAS [30] \\
\hline & Sporulation & non-sporulating & TAS [30] \\
\hline & Temperature range & mesophile & TAS [30] \\
\hline & Optimum temperature & $28^{\circ} \mathrm{C}$ (fish isolates) & IDA \\
\hline & Salinity & usually grows in $4 \%$ of $\mathrm{NaCl}$, but not in $6.5 \%$ & TAS [30] \\
\hline \multirow[t]{3}{*}{ MIGS-22 } & Oxygen & Facultative anaerobe & TAS [30] \\
\hline & Carbon source & $\begin{array}{l}\text { cellobioise, beta-glucoside, trehalose, mannose, lactose, } \\
\text { fructose, mannitol, } \mathrm{N} \text {-acetylgalactosamine, and glucose }\end{array}$ & TAS $[31]$ \\
\hline & Energy source & Chemoorganotroph with fermentative metabolism & TAS [30] \\
\hline MIGS-6 & Habitat & Host & TAS [4] \\
\hline MIGS-15 & Biotic relationship & Symbiotic (pathogen) & TAS [4] \\
\hline \multirow[t]{3}{*}{ MIGS-14 } & Pathogenicity & Cows, human, fishes and other animals & TAS $[12,14]$ \\
\hline & Biosafety level & 2 & TAS [32] \\
\hline & Isolation & Kidney of Nile tilapia & TAS [4] \\
\hline MIGS-4 & Geographic location & Parana state, Brazil & TAS [4] \\
\hline MIGS-5 & Sample collection time & 2006 & TAS [4] \\
\hline MIGS-4.1 & Latitude & not reported & \\
\hline MIGS-4.2 & Longitude & not reported & \\
\hline MIGS-4.3 & Depth & not reported & \\
\hline MIGS-4.4 & Altitude & not reported & \\
\hline
\end{tabular}

Evidence codes - IDA: Inferred from Direct Assay; TAS: Traceable Author Statement (i.e., a direct report exists in the literature); NAS: Non-traceable Author Statement (i.e., not directly observed for the living, isolated sample, but based on a generally accepted property for the species, or anecdotal evidence). These evidence codes are from the Gene Ontology project [33]. If the evidence is IDA, then the property was directly observed for a live isolate by one of the authors or an expert mentioned in the acknowledgements.

Table 2. Genome sequencing project information.

\begin{tabular}{lll}
\hline MIGS ID & Property & Term \\
\hline MIGS-31 & Finishing quality & Finished \\
MIGS-28 & Libraries used & Two mate-paired libraries (mean size 50 or 60 bp, DNA insert size of 1-2Kb) \\
MIGS-29 & Sequencing platforms & SOLiD v3 plus and SOLiD 5500 \\
MIGS-31.2 & Sequencing coverage & $5700 \times$ \\
MIGS-30 & Assemblers & CLC Genome Workbench, Velvet, Edena \\
MIGS-32 & Gene calling method & Glimmer \\
& Genbank ID & CP003919 (chromosome) \\
& Genbank Date of Release & November 02, 2012 \\
& GOLD ID & Gc02347 \\
& Project relevance & Animal and human pathogen \\
\hline
\end{tabular}


After quality analysis, 210,004,694 reads were used in the assembly, which generated a genome coverage corresponding to $\sim 5,700 \times$ genome coverage based on the reference genome of 2,127,839 bp size of $S$. agalactiae strain A909 (NC_007432). The genome sequence of SA20-06 was assembled based on the hybrid strategy using CLC Genome Workbench 4.9, Velvet [39] and Edena [40] software. A total of 872 contigs were generated, with $N_{50}$ of 5,221 bp and the smallest contig having 201 bp. Due to the hybrid assembly methodology, the redundant contigs were removed using the Simplifier software [41]. The contigs were mapped against the reference genome (strain A909) using BLASTn, and the results were analyzed using G4ALL software [42], to extend the contigs and identify overlaps of a minimum of $30 \mathrm{bp}$ between the ends of the contigs, thus yielding larger contigs.

These contigs were later subjected to a finishing process using CLC Genomics Workbench software. At this step, the contigs were ordered and oriented by mapping against the reference genome, yielding a preliminary scaffold with gaps that were removed with recursive rounds of short read mapping against the scaffold [43].

\section{Genome annotation}

For structural annotation, the following software was employed: Glimmer 3, to predict genes [44]; RNAmmer, to predict rRNAs [45]; and tRNAscanSE, to predict tRNAs [46]. Functional annotation was performed by similarity analyses using public databases of National Center for Biotechnology Information (NCBI) non-redundant database, Swiss-Prot and InterProScan analysis [47]. Genome visualization and manual annotation were carried out using Artemis [48].

\section{Genome properties}

The complete genome of $S$. agalactiae strain SA2006 comprises a single circular chromosome of $1,820,886 \mathrm{bp}$ in length with 1,710 putative predicted genes (excluding pseudogenes), 35.56\% $\mathrm{G}+\mathrm{C}$ content, 7 rRNA operons, 79 tRNA genes and 62 pseudogenes (Figure 2 and Table 3). The distribution of genes into the COG functional categories is presented in Table 4.

Table 3. Genome statistics.

\begin{tabular}{lrr}
\hline Attribute & Value & \% of Total $^{\mathbf{a}}$ \\
\hline Genome size (bp) & $1,820,886$ & $100.00 \%$ \\
DNA coding region (bp) & $1,547,993$ & $85.01 \%$ \\
DNA G+C content (bp) & 647,477 & $35.56 \%$ \\
Number of replicons & 1 & \\
Extrachromosomal elements $^{\text {Total genes }}{ }^{\mathrm{b}}$ & 0 & \\
RNA genes & 1,872 & $100.00 \%$ \\
rRNA operons & 100 & $5.34 \%$ \\
Protein-coding genes & 7 & \\
Pseudo genes & 1,772 & $94.66 \%$ \\
Genes with function prediction & 62 & $3.31 \%$ \\
Genes in paralog clusters & 1,515 & $80.93 \%$ \\
Genes assigned to COGs & 430 & $22.97 \%$ \\
Genes assigned Pfam domains & 1,469 & $78.47 \%$ \\
Genes with signal peptides & 1,547 & $82.64 \%$ \\
Genes with transmembrane helices & 302 & $16.13 \%$ \\
\hline
\end{tabular}

a) The total is based on either the size of the genome in base pairs or the total number of protein coding genes in the annotated genome.

b) Also includes 62 pseudogenes. 


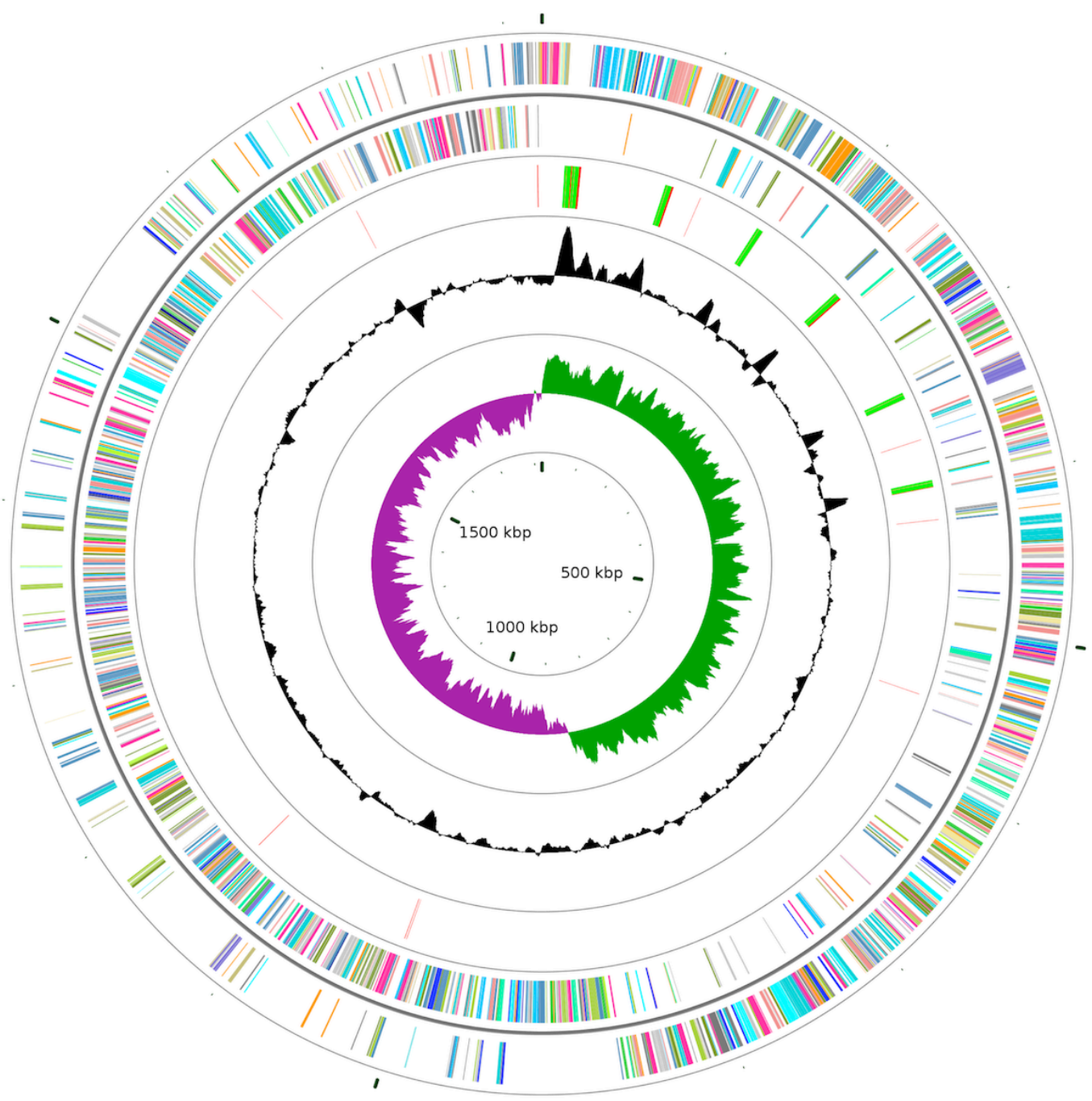


Table 4. Number of genes associated with the general COG functional categories.

\begin{tabular}{crrl}
\hline Code & Value & \%age & Description \\
\hline J & 146 & 9.2 & Translation, ribosomal structure and biogenesis \\
A & 0 & 0.0 & RNA processing and modification \\
K & 118 & 7.44 & Transcription \\
L & 86 & 5.42 & Replication, recombination and repair \\
B & 0 & 0.0 & Chromatin structure and dynamics \\
D & 17 & 1.07 & Cell cycle control, cell division, chromosome partitioning \\
Y & 0 & 0.0 & Nuclear structure \\
V & 36 & 2.27 & Defense mechanisms \\
T & 66 & 4.16 & Signal transduction mechanisms \\
M & 92 & 5.8 & Cell wall/membrane biogenesis \\
N & 6 & 0.38 & Cell motility \\
Z & 0 & 0.0 & Cytoskeleton \\
W & 0 & 0.0 & Extracellular structures \\
U & 21 & 1.32 & Intracellular trafficking and secretion \\
O & 53 & 3.34 & Posttranslational modification, protein turnover, chaperones \\
C & 46 & 2.9 & Energy production and conversion \\
G & 150 & 9.45 & Carbohydrate transport and metabolism \\
E & 134 & 8.44 & Amino acid transport and metabolism \\
F & 75 & 4.73 & Nucleotide transport and metabolism \\
H & 52 & 3.28 & Coenzyme transport and metabolism \\
I & 43 & 2.71 & Lipid transport and metabolism \\
P & 86 & 5.42 & Inorganic ion transport and metabolism \\
Q & 19 & 1.2 & Secondary metabolites biosynthesis, transport and catabolism \\
R & 192 & 12.10 & General function prediction only \\
S & 149 & 9.39 & Function unknown \\
- & 403 & 21.53 & Not in COGs \\
\hline & & &
\end{tabular}

\section{Conclusions}

Further analysis of the SA20-06 genome is now under way, with the objective of identifing specific factors that might explain the differences in

\section{Acknowledgement}

This work was supported by Ministério da Pesca e Aquicultura, Furnas Centrais Elétricas, Conselho Nacional de Desenvolvimento Científico e Tecnológico (CNPq) and Fundação de Amparo à Pesquisa do Estado

\section{References}

1. Rajagopal L. Understanding the regulation of Group B Streptococcal virulence factors. Future Microbiol 2009; 4:201-221. PubMed http://dx.doi.org/10.2217/17460913.4.2.201 pathogenesis of disease, mainly in heterothermic hosts.

de Minas Gerais (FAPEMIG). We also acknowledge support from the Coordenação de Aperfeiçoamento de Pessoal de Nível Superior (CAPES) and Rede Paraense de Genômica e Proteômica.

2. Richards VP, Lang P, Bitar PD, Lefébure T, Schukken YH, Zadoks RN, Stanhope MJ. Comparative genomics and the role of lateral gene transfer in the evolution of bovine adapted Streptococcus agalactiae. Infect Genet Evol 2011; 
11:1263-1275. PubMed

http://dx.doi.org/10.1016/j.meegid.2011.04.019

3. Evans JJ, Klesius PH, Gilbert PM, Shoemaker CA, Al Sarawi MA, Landsberg J, Duremdez R, Al Marzouk A, Al Zenki S. Characterization of $\beta$ haemolytic Group B Streptococcus agalactiae in cultured seabream, Sparus auratus L., and wild mullet, Liza klunzingeri (Day), in Kuwait. J Fish Dis 2002; 25:505-513.

http://dx.doi.org/10.1046/j.1365-

2761.2002.00392.x

4. Mian GF, Godoy DT, Leal CAG, Yuhara TY, Costa GM, Figueiredo HCP. Aspects of the natural history and virulence of $\mathrm{S}$. agalactiae infection in Nile tilapia. Vet Microbiol 2009; 136:180-183. PubMed http://dx.doi.org/10.1016/j.vetmic.2008.10.016

5. Duremdez R, Al-Marzouk A, Qasem JA, Al-Harbi A, Gharabally H. Isolation of Streptococcus agalactiae from cultured silver pomfret, Pampus argenteus (Euphrasen), in Kuwait. J Fish Dis 2004; 27:307-310. PubMed http://dx.doi.org/10.1111/j.13652761.2004.00538.x

6. Tettelin H, Masignani $\mathrm{V}$, Cieslewicz MJ, Donati C, Medini D, Ward NL, Angiuoli SV, Crabtree J, Jones AL, Durkin AS. Genome analysis of multiple pathogenic isolates of Streptococcus agalactiae: Implications for the microbial "pangenome.". Proc Natl Acad Sci USA 2005; 102:13950-13955. PubMed http://dx.doi.org/10.1073/pnas.0506758102

7. Schuchat A. Epidemiology of group B streptococcal disease in the United States: shifting paradigms. Clin Microbiol Rev 1998; 11:497-513. PubMed

8. Lancefield RC. A serological differentiation of specifc types of bovine hemolytic streptococci (GROUP B). J Exp Med 1934; 59:441-458. PubMed http://dx.doi.org/10.1084/jem.59.4.441

9. Slotved HC, Kong F, Lambertsen L, Sauer S, Gilbert GL. Serotype IX, a Proposed New Streptococcus agalactiae Serotype. I Clin Microbiol 2007; 45:2929-2936. PubMed http://dx.doi.org/10.1128//CM.00117-07

10. Carvalho MG, Facklam R, Jackson D, Beall B, McGee L. Evaluation of three commercial broth media for pigment detection and identification of a group B Streptococcus (Streptococcus agalactiae). J Clin Microbiol 2009; 47:4161-4163. PubMed http://dx.doi.org/10.1128//CM.01374-09
11. Brochet M, Couvé E, Zouine M, Vallaeys T, Rusniok C, Lamy M, Buchrieser C, Trieu-Cout P, Kunst F, Poyart C, Glaser P. Genomic diversity and evolution within the species Streptococcus agalactiae. Microbes Infect 2006; 8:1227-1243. PubMed http://dx.doi.org/10.1016/j.micinf.2005.11.010

12. Bisharat N, Crook DW, Leigh J, Harding RM, Ward PN, Coffey TJ, Maiden MC, Peto T, Jones N. Hyperinvasive Neonatal Group B Streptococcus Has Arisen from a Bovine Ancestor. / Clin Microbiol 2004; 42:2161-2167. PubMed http://dx.doi.org/10.1128/JCM.42.5.2161$\underline{2167.2004}$

13. Robinson JA, Meyer FP. Streptococcal Fish Pathogen. J Bacteriol 1966; 92:512. PubMed

14. Pereira UP, Mian GF, Oliveira ICM, Benchetrit LC, Costa GM, Figueiredo HCP. Genotyping of Streptococcus agalactiae strains isolated from fish, human and cattle and their virulence potential in Nile tilapia. Vet Microbiol 2010; 140:186-192. PubMed http://dx.doi.org/10.1016/j.vetmic.2009.07.025

15. Field D, Garrity G, Gray T, Morrison N, Selengut J, Sterk P, Tatusova T, Thomson N, Allen MJ, Angiuoli SV. The minimum information about a genome sequence (MIGS) specification. Nat Biotechnol 2008; 26:541-547. PubMed http://dx.doi.org/10.1038/nbt1360

16. Woese CR, Kandler O, Wheelis ML. Towards a natural system of organisms: proposal for the domains Archaea, Bacteria, and Eucarya. Proc Natl Acad Sci USA 1990; 87:4576-4579. PubMed http://dx.doi.org/10.1073/pnas.87.12.4576

17. Gibbons NE, Murray RGE. Proposals Concerning the Higher Taxa of Bacteria. Int J Syst Bacteriol 1978; 28:1-6. http://dx.doi.org/10.1099/00207713-28-1-1

18. Garrity GM, Holt JG. The Road Map to the Manual. In: Garrity GM, Boone DR, Castenholz RW (eds), Bergey's Manual of Systematic Bacteriology, Second Edition, Volume 1, Springer, New York, 2001, p. 119-169.

19. Murray RGE. The Higher Taxa, or, a Place for Everything...? In: Holt JG (ed), Bergey's Manual of Systematic Bacteriology, First Edition, Volume 1, The Williams and Wilkins Co., Baltimore, 1984, p. 31-34.

20. Euzéby J. List of new names and new combinations previously effectively, but not validly, published. List no. 132. Int / Syst Evol Microbiol 
2010; 60:469-472.

http://dx.doi.org/10.1099/ijs.0.022855-0

21. Ludwig W, Schleifer KH, Whitman WB. Class I. Bacilli class nov. In: De Vos P, Garrity G, Jones D, Krieg NR, Ludwig W, Rainey FA, Schleifer KH, Whitman WB (eds), Bergey's Manual of Systematic Bacteriology, Second Edition, Volume 3, Springer-Verlag, New York, 2009, p. 19-20.

22. Ludwig W, Schleifer KH, Whitman WB. Order II. Lactobacillales ord. nov. In: De Vos P, Garrity G, Jones D, Krieg NR, Ludwig W, Rainey FA, Schleifer KH, Whitman WB (eds), Bergey's Manual of Systematic Bacteriology, Second Edition, Volume 3, Springer-Verlag, New York, 2009, p. 464.

23. Skerman VBD, McGowan V, Sneath PHA. Approved Lists of Bacterial Names. Int J Syst Bacteriol 1980; 30:225-420. http://dx.doi.org/10.1099/00207713-30-1-225

24. Deibel RH, Seeley HW. Family II. Streptococcaceae. In: Buchanan RE, Gibbons NE (eds), Bergey's Manual of Determinative Bacteriology, Eighth Edition, The Williams and Wilkins Co., Baltimore, 1974, p. 490-515.

25. Rosenbach FJ. In: Bergmann JF (ed), Microorganismen bei den Wund-InfectionsKrankheiten des Menschen., Wiesbaden, 1884, p. 1-122.

26. Deibel RH, Seeley HW. Genus I. Streptococcus Rosenbach 1884, 22. In: Buchanan RE, Gibbons NE (eds), Bergey's Manual of Determinative Bacteriology, Eighth Edition, The Williams and Wilkins Co., Baltimore, 1974, p. 490-509.

27. Lehmann KB, Neumann R. Atlas und Grundriss der Bakteriologie und Lehrbuch der speziellen bakteriologischen Diagnostik, First Edition, J.F. Lehmann, München, 1896, p. 1-448.

28. Judicial Commission. Opinions 4, 6, 7, 8, 9, 10, 11, 12, 13, 14 Opinion 8. Int Bull Bacteriol Nomencl Taxon 1954; 4:141-158.

29. Judicial Commission. Opinion 27: Designation of the neotype strain of Streptococcus agalactiae Lehmann and Neumann. Int Bull Bacteriol Nomencl Taxon 1963; 13:37.

30. Whiley RA, Hardie JM. The Firmicutes. In: Garrity GM, Boone DR, Castenholz RW (eds), Bergey's Manual of Systematic Bacteriology, Second Edition, Volume 3, Springer, New York, 2001, p. 655-735.

31. Glaser P, Rusniok C, Buchrieser C, Chevalier F, Frangeul L, Msadek T, Zouine M, Couvé E,
Lalioui L, Poyart C. Genome sequence of Streptococcus agalactiae, a pathogen causing invasive neonatal disease. Mol Microbiol 2002; 45:14991513. PubMed http://dx.doi.org/10.1046/j.13652958.2002.03126.x

32. Moura H, Woolfitt AR, Carvalho MG, Pavlopoulos A, Teixeira LM, Satten GA, Barr JR. MALDI-TOF mass spectrometry as a tool for differentiation of invasive and noninvasive Streptococcus pyogenes isolates. FEMS Immunol Med Microbiol 2008; 53:333-342. PubMed http://dx.doi.org/10.1111/j.1574695X.2008.00428.x

33. Ashburner M, Ball CA, Blake JA, Botstein D, Butler H, Cherry JM, Davis AP, Dolinski K, Dwight SS, Eppig JT, et al. Gene ontology: tool for the unification of biology. The Gene Ontology Consortium. Nat Genet 2000; 25:25-29. PubMed http://dx.doi.org/10.1038/75556

34. Poyart C, Pellegrini E, Gaillot O, Boumaila C, Baptista M, Trieu-Cuot P. Contribution of Mncofactored superoxide dismutase (SodA) to the virulence of Streptococcus agalactiae. Infect Immun 2001; 69:5098-5106. PubMed http://dx.doi.org/10.1128/IAI.69.8.5098$\underline{5106.2001}$

35. Larkin MA, Blackshields G, Brown NP, Chenna R, McGettigan PA, McWilliam H, Valentin F, Wallace IM, Wilm A, Lopez R, et al. Clustal W and Clustal X version 2.0. Bioinformatics 2007; 23:2947-2948. PubMed http://dx.doi.org/10.1093/bioinformatics/btm404

36. Tamura K, Peterson D, Peterson N, Stecher G, Nei M, Kumar S. MEGA5: molecular evolutionary genetics analysis using maximum likelihood, evolutionary distance, and maximum parsimony methods. Mol Biol Evol 2011; 28:2731-2739. $\underline{\text { PubMed }}$ http://dx.doi.org/10.1093/molbev/msr121

37. Liolios K, Chen IM, Mavromatis K, Tavernarakis N, Hugenholtz P, Markowitz VM, Kyrpides NC. The Genomes On Line Database (GOLD) in 2009: status of genomic and metagenomic projects and their associated metadata. Nucleic Acids Res 2010; 38:D346-D354. PubMed http://dx.doi.org/10.1093/nar/gkp848

38. Bollet C, Gevaudan MJ, de Lamballerie X, Zandotti C, de Micco P. A simple method for the isolation of chromosomal DNA from Gram positive or acid-fast bacteria. Nucleic Acids Res 1991; 19:1955. PubMed http://dx.doi.org/10.1093/nar/19.8.1955 
39. Zerbino DR, Birney E. Velvet: algorithms for de novo short read assembly using de Bruijn graphs. Genome Res 2008; 18:821-829. PubMed http://dx.doi.org/10.1101/gr.074492.107

40. Hernandez D, François P, Farinelli L, Osterås M, Schrenzel J. De novo bacterial genome sequencing: millions of very short reads assembled on a desktop computer. Genome Res 2008; 18:802809. PubMed http://dx.doi.org/10.1101/gr.072033.107

41. Tsai IJ, Otto TD, Berriman M. Improving draft assemblies by iterative mapping and assembly of short reads to eliminate gaps. Genome Biol 2010; 11:R41. PubMed http://dx.doi.org/10.1186/gb2010-11-4-r41

42. G4ALL. http://g4all.sourceforge.net

43. Ramos RTJ, Carneiro AR, Azevedo V, Schneider MP, Barh D, Silva A. Simplifier: a web tool to eliminate redundant NGS contigs. Bioinformation 2012; 8:996-999. PubMed http://dx.doi.org/10.6026/97320630008996

44. Delcher AL, Harmon D, Kasif S, White O, Salzberg SL. Improved microbial gene identification with GLIMMER. Nucleic Acids Res 1999; 27:4636-4641. PubMed http://dx.doi.org/10.1093/nar/27.23.4636
45. Lagesen K, Hallin P, Rodland EA, Staerfeldt HH, Rognes T, Ussery DW. RNAmmer: consistent and rapid annotation of ribosomal RNA genes. Nucleic Acids Res 2007; 35:3100-3108. PubMed http://dx.doi.org/10.1093/nar/gkm160

46. Lowe TM, Eddy SR. tRNAscan-SE: A Program for Improved Detection of Transfer RNA Genes in Genomic Sequence. Nucleic Acids Res 1997; 25:955-964. PubMed

47. Zdobnov EM, Apweiler R. InterProScan -- an integration platform for the signature-recognition methods in InterPro. Bioinformatics 2001; 17:847848. PubMed http://dx.doi.org/10.1093/bioinformatics/17.9.847

48. Rutherford K, Parkhill J, Crook J, Horsnell T, Rice P, Rajandream MA, Barrell B. Artemis: sequence visualization and annotation. Bioinformatics 2000; 16:944-945. PubMed http://dx.doi.org/10.1093/bioinformatics/16.10.94 $\underline{4}$

49. Grant JR, Arantes AS, Stothard P. Comparing thousands of circular genomes using the CGView Comparison Tool. BMC Genomics 2012; 13:202. PubMed http://dx.doi.org/10.1186/1471-2164-13$\underline{202}$ 